\title{
Teaching Models to Increase Students' Analytical Thinking Skills
}

\author{
Septi Budi Sartika \\ Fakultas Keguruan dan Ilmu Pendidikan \\ Universitas Muhammadiyah Sidoarjo \\ Sidoarjo, Indonesia \\ septibudisartika@umsida.ac.id
}

\begin{abstract}
Thinking skills is a trained skill according to the Curriculum-2013, ie analytical thinking skills rather than mechanistic thinking (routine). Analytical thinking skills can be improved through a particular learning model or learning strategy. This study examines learning models that improve analytical thinking skills. The learning models include Guided Inquiry, Problem Based Learning (PBL) model, Group Investigation model, Context Based Learning Model (CBL), and Model of Analytical Thinking Skills Training Process. The strategies used in improving analytical thinking skills include MURDER (Mood, Understand, Recall, Digest, Expand, Review) and Infographics (Information and Graphics). Based on the result of the study, it is found that the model and learning strategy to improve analytical thinking skills generally start from a problem, then the problem is formulated to be proved together with the group by searching relevant information, observation/ experiment, and conclude the obtained result, and communicate. The weaknesses of each model and learning strategy will be studied in developing valid, practical, and effective learning models in teaching analytical thinking skills.
\end{abstract}

Keyword- learning model; analytical thinking skills; MURDER

\section{INTRODUCTION}

Analysis and evaluation of the necessary skills is recognized every student in a variety of scientific fields, such as analyzing the poem, mathematical formula, biology system, chapter in the text book, concepts and ideas, essays, novels, and articles[11]. Synthesis and evaluation of skill needs analysis [10]. According to the Judge, et al [9], analytical thinking skills will be meaningful in some aspect of the field of study, for example, when listening to the lesson, contribute in a seminar or publish the work. The analysis is used to identify the intense relationships and actual for statements, questions, concepts, descriptions or form of representation to express belief, justification, experiences, reactions, information, and opinions [12]. Critical analysis of student thinking in each field of science as well as for specific purposes.

Natural Sciences is a scientific discipline that studies the natural symptoms as well as their interaction. Nature of Natural Science consists of the scientific attitude, scientific processes, and scientific products. The scientific process is what is known as the scientific method. According to Carey [6], simple scientific method consists of 3 (three) process that is to observe, describe, and test of the events described. Analysis skills in this case is at the third process, in observing requires the analysis of elements (parts), in explaining the needs analysis the relationship that is the link between the parts, and in testing the need analysis the system i.e. know the elements and their relationship in the organized structure. According to Raiyn \& Tilchin [17]that high level thinking skills needed in solving problems such as analysis and creative thinking skills. Having regard to the annotations, then the analysis is also closely related to the settlement of the issue, particularly for the field of Natural Science.

Natural Science learning in secondary school we recommend: 1) can foster confidence that students are capable of in Natural Science and is not a lesson that should be feared; 2) to teach Natural Science not only the concepts, but also comes with a scientific attitude and skill development (domain knowledge and cognitive processes); 3) learning the Natural Science provide a learning experience that is reasoning, developed the ability to plan and conduct a scientific inquiry, using knowledge already learnt to understand the nature of the symptoms that occur in the vicinity; and 4) revitalize the science process skills for students, teachers, and aspiring teachers as the primary mission of teaching and learning science in school to develop their ability of observation, planning the investigation, interpreting (interpretation) data and information (narration, pictures, charts, tables) as well as drawing conclusions [13]. Thus it is important existence to improve thinking skills of analysis in developing reasoning ability, plan and conduct a scientific inquiry, using knowledge already learnt to understand the symptoms of nature occur in the vicinity.

To teach the skills needs of the learning model. According to Arends [3] that learning refers to learning approach will be used, including the teaching objectives, namely, the stages in the learning environment, learning activities, and classroom management. The teaching model is a tool to help teachers, good teaching more effectively and make more systematic instruction, but does not replace the skills of teaching [8].

Learning models that are able to increase the thinking skills of analysis is a model based on constructivist theory. Learning models that can improve analytical thinking skills of which 1) model guided inquiry [15]; 2) model of Problem Based Learning (PBL) [5, 16, 7]; 3) model group investigation [19]; 4) model Context Based Learning (CBL)[18]; 5) Model Of Analytical Thinking Skills Training Process [14]; 6) strategy of Mood, Understand, Recall, Digest, Expand, Review (MURDER) [4]; 7) strategy infographics [7]. 


\section{RESEARCH METHOD}

Research methods of library studies using techniques drawn from empirical studies based on fifteen scientific articles.

\section{DISCUSSION}

Teaching models that can improve analytical thinking skills as follows:

1. Model of Guided Inquiry

A model of Guided inquiry [15] has the following syntax:

1) formulating the problem, formulate hypotheses, 2) 3)

collect data, and 4) to make the conclusion. The advantages of the model include: (1) understand the basic concepts and ideas better; (2) help in using memory and transfer in the learning process; (3) encourage the students to think and work on its own initiative; (4) encourage the students to think intuitively and formulate your own hypotheses; (5) decision that is of delivers.

2. Model Of Problem Based Learning (PBL)

PBL models according to [3] has the syntax: 1) orienting students on the issues, 2) designing the process of solving problems with the scientific method/organizing the students to learn, 3) independent investigation/group guide, 4) developed and presents the results of the work and show it off, and 5) analyze and evaluate the process of problem solving. Weaknesses of PBL model [5], [16], and [7]including: (1) performance assessment so that tend to require a valid measurement techniques and reliability are the challenges facing teachers, In addition the rate of completion of the different tasks between students.

3. Models Group Investigation

Model Group Investigation examined [19]has the following steps: 1) Group was formed by students of their own teridri over 2-6 people, 2) each group is free to choose a sub topic of the whole unit material, and 3) results the report of the group. The advantages of the model group investigation is improve the way teachers teaching from teacher-centered became centred on the student and allows students to do different learning experiences such as suggested and explain everything that is sourced from mind yourself, open yourself to think of friends, increase the responsibility of the students in learning and improve achievement.

4. Model of Context Based Learning (CBL)

The model developed [18] has the syntax: orientation, organization, examination, experimentation, and communication. The advantages of the model CBL whom effectively to improve thinking and analysis is recommended to be performed with a different subject.

5. Models of Analytical Thinking Skills Training Process

The model developed [14] has no special name. This model has the syntax of warm-ups, demonstration of skill, step by step coaching, full step coaching, and evalution. This model has the advantages of being able to help develop critical thinking skills of a person towards a higher level and used to teach in Thailand to resolve a problem that requires thinking skills analysis for students in the future.
6. The strategy of Mood, Understand, Recall, Digest, Expand, Review (MURDER)

The strategy of MURDER according to its name, the learning steps steps starting with the mood, understand, recall, digest, expand, and reviews. Models examined [4]has the advantages of which 1) each stage in the strategy for enhancing the role of the MURDER have the thinking ability of students, 2) analysis to assist students in developing a learning system that is effective and efficient, 3) help students to increase understanding, to train students to think the analysis, and elaborated the concept of thinking ability analysis.

7. The strategy of Infographics

The strategy of infographics [1] has the following steps: 1) choose the main idea, 2) drawing introduction, 3) choosing a topic and sub-topic 4) skillfully made designs as the Union units, 5) choose colors, 6) revised the design, 7) represents the entire contents, 8) assure the authenticity of the pictures, and 9) final production. The advantage of this strategy, effective in improving analytical thinking skills.

Based on empirical studies, it can be claimed that each study has not fully taught analytical thinking skills in accordance with Bloom Taxonomy Revision[2]indicators of analysis, such as: differentiating, organizing, and attributing.

\section{CONCLUSIONS}

Based on the deliberations of the conclusion that the model can be obtained and learning strategies to improve thinking skills analysis generally starts from a problem, then the problem is formulated for proven along her group by searching for relevant information, observations/experiments, and concluded the results obtained, as well as communicate.

The disadvantages of each model and learning strategies will be examined in developing learning models are valid, practical, and effective in teaching analytical thinking skills.

The researcher's suggestion, to develop a learning model that specifically teaches analytical thinking needs an indicator of analysis to find out whether each syntax also trains analytical thinking skills.

\section{ACKNOWLEDGEMENTS}

The authors give thanks for this article has done as a form of preliminary studies in a learning model that is capable of digging teach analytical thinking skills specifically. The authors say thanks to Dr. Nur Efendi, M. Pd. as Dean of the Faculty of teacher training and Science Educational Universitas Muhammadiyah Sidoarjo, Fitria Eka Wulandari, S.Si., M. Pd., as the Chairman Natural Science Education Program, and Lecturers in Natural Science Education Program.

\section{REFERENCES}

Al-Mohammadi, Najwa, "Effectiveness of Using Infographics As An Approach for Teaching Programming Fundamental on DevelopingAnalytical Thinking Skills for High School Students" Makkah: University of Jeddah. Global Jounal of Educational Studies 
ISSN: 377-3936 Vol.3 No.1. doi: 10.5296/gjes.v3i1.10854 URL: http://dx.doi.org/10.5296/gjes.v3il.10854., 2017.

[2] Anderson dan Krathwol,:A Revision Bloom's Taxonomy of Educational Objectives". New York: Addison Wesley Longman, Inc., 2001.

[3] Arends, Richard I,"Learning to Teach $9^{\text {th }}$." Singapore: Mc. Graw-Hill Companies, Inc., 2012.

[4] Asani, Diksa, "Efektivitas Strategi Pembelajaran MURDER terhadap Partisipasi dan Kemampuan Berpikir Analisis Siswa". Surakarta: Universitas Sebelas Maret., 2012.

[5] Atikasari, Sandra, dkk, "Pengaruh Pembelajaran PBL dalam Materi Pencemaran Lingkungan terhadap Kemampuan Analisis". http://journal.unnes.ac.id/sju/index.php/ujeb, 2012.

[6] Carey, Stephen S,“A Beginner Guide to Sciencetific Method 4th Edition”. United States: Wodsworth., 2011.

[7] Carolina, Novita, dkk, "Pengaruh Model Memelihara Transmisi Berbasis PBL untuk Meningkatkan Kemampuan Analisis Siswa". Surabaya: UNESA., 2014.

[8] EggendanKauchak,"Strategies and Models for Teacher: Teaching Content and Thinking Skills $1^{\text {st }}$ Edition". University of North Florida., 2009.

[9] Judge, et al, "Critical Thinking Skills for Education Students. UK: TJ International Ltd, Padstow, Cornwall., 2009.

[10] Ennis, Robert H, "Critical Thinking Assessment:Theory into Practice”, Vol. 32, Number 3, Summer 1993, Copyright 1993 College of Education, The OHIO State University., 2001.

[11] Elder, Linda dan Richard Paul, "Analytical Thinking How to Take Thinking Apart and What to Look for When You do". Based on Critical
Thinking concepts \& tools. A companion to: The Miniature Guide to Critical Thinking Concepts and Tools., 2007.

[12] Facione, Peter A "Critical Thinking: What It Is and Why It Counts", jmorante@insightassessment.comISBN 13: 978-1-891557-07-1. Facione \& Gittens, Pearson Education 2013

[13] Lampiran Permendikbud No. 68 Tahun 2013.

[14] Montaku, Sudjit et al, "The Model Of Analytical Thinking Skill Training Process". Research Journal of Applied Sciences 7 (1) 17-20, 2012 ISSN: 1815-932X. Medwell Journal., 2012.

[15] Pertiwi, Nurhayati Ike, dkk, "Penerapan Model Guided Inquiry Berbantu Twitter untuk Meningkatkan Kemampuan Berpikir Analitis Biologi Siswa”. Surakarta: UNS., 2012.

[16] Rahmawati, dkk, "Pengaruh Model Pembelajaran Problem Based Learning terhadap Kemampuan Berpikir Analitis". Malang: Universitas Negeri Malang., 2013.

[17] Raiyn \& Tilchin, "Higher-Order Thinking Development through Adaptive Problem Based Learning”. Journal of Education and Training Studies. Vol. 3, No. 4; July 2015. ISSN 2324-805X E-ISSN 2324-8068 Published by Redfame Publishing. URL: http://jets.redfame.com.

doi:10.11114/jets.v3i4.769.URL:http://dx.doi.org/10.11114/jets.v3i4.7 $69,2015$.

[18] Sudibyo, Elok et al,"The Effectiveness of CBL Models to improve Analytical Thinking Skills The Studentof Sport Science”. International Education Studies; Vol. 9, No. 4; 2016. ISSN 1913-9020 e-ISSN 1913-9039. Doi: 10.5539/ies.v9n4p195. URL: http://dx.doi.org/10.5539/ies.v9n4p195, 2016.

[19] Yuli E, Neilna, "Model Pembelajaran Group Investigation terhadap Kemampuan Berpikir Analisis”. Malang: Universitas Negeri Malang., 2012. 